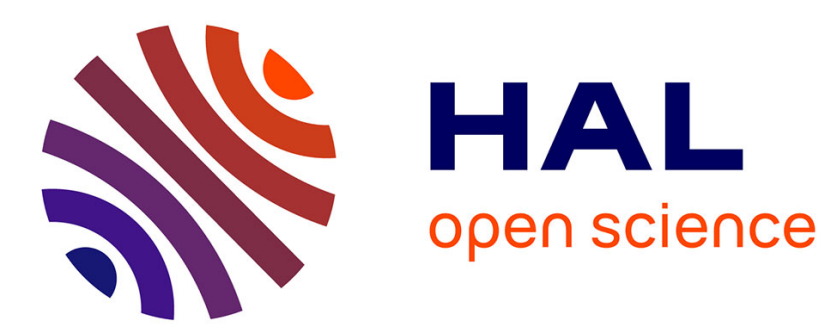

\title{
The impact of palm oil feedstock within the LCA of a bio-sourced cosmetic cream
}

\author{
Sylvain Martinez, C. Bessou, Léa Hure, J. Guilbot, Arnaud Helias
}

\section{To cite this version:}

Sylvain Martinez, C. Bessou, Léa Hure, J. Guilbot, Arnaud Helias. The impact of palm oil feedstock within the LCA of a bio-sourced cosmetic cream. Journal of Cleaner Production, 2017, 145, pp.348360. 10.1016/j.jclepro.2017.01.042 . hal-01605842

\section{HAL Id: hal-01605842 \\ https://hal.science/hal-01605842}

Submitted on 26 May 2020

HAL is a multi-disciplinary open access archive for the deposit and dissemination of scientific research documents, whether they are published or not. The documents may come from teaching and research institutions in France or abroad, or from public or private research centers.
L'archive ouverte pluridisciplinaire HAL, est destinée au dépôt et à la diffusion de documents scientifiques de niveau recherche, publiés ou non, émanant des établissements d'enseignement et de recherche français ou étrangers, des laboratoires publics ou privés. 


\section{Accepted Manuscript}

The impact of palm oil feedstock within the LCA of a bio-sourced cosmetic cream

S. Martinez, C. Bessou, L. Hure, J. Guilbot, A. Hélias

PII: S0959-6526(17)30049-5

DOI: $\quad$ 10.1016/j.jclepro.2017.01.042

Reference: JCLP 8789

To appear in: Journal of Cleaner Production

Received Date: 1 June 2016

Revised Date: 23 December 2016

Accepted Date: 9 January 2017

Please cite this article as: Martinez S, Bessou C, Hure L, Guilbot J, Hélias A, The impact of palm oil feedstock within the LCA of a bio-sourced cosmetic cream, Journal of Cleaner Production (2017), doi: 10.1016/j.jclepro.2017.01.042.

This is a PDF file of an unedited manuscript that has been accepted for publication. As a service to our customers we are providing this early version of the manuscript. The manuscript will undergo copyediting, typesetting, and review of the resulting proof before it is published in its final form. Please note that during the production process errors may be discovered which could affect the content, and all legal disclaimers that apply to the journal pertain. 
17254 words for full text + figures and tables, 336 words for title + authors and affiliations + abstract,

21662 words for references

3 The impact of palm oil feedstock within the LCA of a bio-sourced cosmetic

4

5

6

7

8

9 cream

S. Martinez ${ }^{a, b}$ C. Bessou ${ }^{c, b}$, L. Hure ${ }^{a, b}$ J. Guilbot ${ }^{d}$, A. Hélias ${ }^{a, b}$

\section{a'LBE, Montpellier SupAgro, INRA, 102 avenue des Etangs, 11100, Narbonne, France}

${ }^{\mathrm{b}}$ Elsa, Research group for Environmental Lifecycle Sustainability Assessment, Montpellier SupAgro, 2 place Pierre Viala, 34060, Montpellier, France

${ }^{\mathrm{C} C I R A D}$, UPR Systèmes de pérennes, 34398 Montpellier, France

${ }^{\mathrm{d}}$ SEPPIC, 81100, Castres, France

Keywords: Life cycle assessment, Cosmetic, Palm oil, Peat soil, Deforestation, Land Use

Abstract

We performed a cradle-to-grave life cycle assessment (LCA) of a bio-based cosmetic cream containing Refined Palm Kernel Oil (RPKO). The objective was to investigate the importance of the RPKO production within the environmental impact of the cosmetic cream. We assumed a baseline scenario with best oil palm agricultural practices in Malaysia, and then tested different parameters, i.e. deforestation, peat soil drainage and improved effluent treatment, in order to check their influences.

In the baseline scenario, transport of the cosmetic cream was the main contributing process (largest contribution for 11 out of 15 impact indicators). Contribution of the packaging of the cosmetic cream was also significant (largest for 2 out of 15). RPKO had a low impact contribution in the baseline scenario, albeit a much more critical one in the alternative scenarios. Deforestation and peat soil drainage (i.e. transformation and occupation) influenced two environmental indicators: Climate Change and Land Use. On Climate change indicator, deforestation caused an increase of about $9 \%$ of 
the cosmetic cream impacts and peat soil occupation an increase of $16 \%$. On Land Use indicator, deforestation caused an increase of 3\%, peat soil transformation and occupation caused increases of $938 \%$ and $41 \%$, respectively. Methane capture from palm oil mill effluent treatment and conversion to electricity represented a low decrease of environmental impact of cosmetic cream (from $-0.1 \%$ to $-2.8 \%)$. This paper showed that the palm oil agricultural phase could have a non-negligible impact over the life-cycle of a cosmetic cream in case of deforestation and peat cultivation, despite its small contribution in both mass and economic terms.

\section{Introduction}

Assessing environmental impacts has become mainstream when designing new or improved production systems. It is particularly crucial when promoting new bio-based products that are meant to displace their fossil equivalents in order to reduce the overall environmental impact. Arguments put forward are the renewable aspect and the independence from oil or mineral, implicitly promising low environmental impacts. However, several studies have shown that net environmental benefits from bio-sourced products are not automatic and depend on the studied commodity chain and the way it is assessed (Fargione et al., 2008; Farrel et al., 2006; Gibbs et al., 2008; Gnansounou et al., 2009).

Life Cycle Assessment (LCA) has been widely applied to assess the impact of bio-sourced product (ADEME and BIO Intelligence Service, 2010; JRC et al., 2008; Secchi et al., 2016). LCA holistic approach allows for comparing commodity chains while avoiding hidden problem shifting between stages or environmental impacts. It can integrate the whole life cycle of the product (from cradle to grave), i.e. starting with extraction of raw materials until the end of life of the used product, and assesses a wide range of potential environmental impacts.

The aim of this study is to assess the environmental impacts of a bio-sourced moisturizing cream applying LCA. This cream contains an alkyl polyglucoside (APG) surfactant based on palm oil. Palm oil is nowadays the most used vegetable oil worldwide, accounting in 2015 for $28.3 \%$ of the global oils and fats production (European Palm Oil Alliance, 2015). About 19\% of total palm oil production is used as oleo-chemicals, especially palm kernel oil (Rival and Levang, 2014). Various LCA on palm oil and palm oil-based products have shown that the feedstock production at the farm stage is a major contributor to most of potential environmental impacts (Boonrod et al., 2016; Chavalparit et al., 2006; Choo et al., 2011; Chuchuoy et al., 2009; Nilsson et al., 2010; Schmidt, 2007; Yusoff and Hansen, 2007). This large contribution of the farm stage, due to combined high input levels in the field and low input levels at the mill and refinery stages, remains a key issue when including further 
processing stages to convert palm oil into biodiesel (Achten et al., 2010; Angarita et al., 2009; Arvidsson et al., 2011; Choo et al., 2011; Harsono et al., 2012; Papong et al., 2010; Pleanjai et al., 2009). Focusing on global warming impact, main contributors are GHG emissions during the farm stage and methane emissions from palm oil mill effluent treatment (POME). Whereas the impact from POME can be drastically reduced if the biogas is captured (Choo et al., 2011; Chuchuoy et al., 2009) and further used at the mill stage (Chavalparit et al., 2006), the impact from the farm stage becomes overwhelming when forests or peat soil areas are converted to palm plantations (Reijnders and Huijbregts, 2008; Schmidt, 2007; Wicke et al., 2008; Zulkifli et al., 2009)

In this paper, we investigated the relative contributions of the various production phases of the moisturizing cream over its life cycle from cradle to grave, i.e. from the palm oil production up to the cream use. The first objective was to appraise the impact of the palm oil derivative within the whole supply chain of the moisturizing cream. Then, we focused on exploring how various palm oil production alternatives may critically influence the final LCA results of the bio-based used cream. We first described the implementation of the LCA following ISO norms and International Life Cycle Data (ILCD) guidelines. We then analysed and discussed the influence of the palm oil production scenarios in light of the overall environmental impacts of the studied moisturizing cream.

\section{Material and methods}

\section{$2.1 \quad$ LCA goal and scope}

We implemented LCA according to ISO norms 14040 series and following recommendations from the ILCD (EC-JRC, 2011). We used primary data, where available, and we used Simapro v.8 software with Ecoinvent v. 3 database for background inventories. For palm oil feedstock, we used mixed primary and secondary data from the literature to model the plantation management and the industrial plant. Field emission models are detailed in sub-section 2.2.1.3. For the other biomass feedstock, we relied on Ecoinvent processes. Finally, for the industrial processing of the cosmetic cream, we used primary data from a site-specific industry (Guilbot et al., 2013) and secondary data for the background processes, e.g. electricity production and related emissions. ILCD guidelines define a set of 16 recommended impacts categories, which were applied in this study, except for Water Depletion due to some inconsistencies between the water impact assessment method and Ecoinvent v. 3 database.

The studied functional unit was the preparation and use of one $30 \mathrm{~g}$ jar of cosmetic cream (Guilbot et al., 2013). The production system consisted of 8 main stages (Fig. 1). We first considered an average palm plantation located in Malaysia (stages 1-2), including all transports from the manufacture sites 
to the field for field inputs and from the plantation gate to the mill for the fruits. Malaysia is the second world producer of palm oil and the most described system in life cycle inventory studies. The palm oil transformation into cetearyl alcohol (Transesterification \& Hydrogenation) was assumed to take place in Germany (stage 3), including transport of palm kernel oil from Malaysia to Germany. The wheat production providing the D-glucose was assumed to be located in Northern France (stages 4-5), as well as the final processing step including the production of alkyl polyglucoside (APG) and the final cosmetic cream in accordance with primary data collected by the industry (stages 6-7). We added transport of D-glucose from the Northern (wheat production site) to the Southern part of France, where the final cream production occurred. We finally considered that the cosmetic cream was sold and use in Europe (stage 8), hence accounting for average European market conditions and adding transportation of cosmetic cream from manufacturer to retailer, from retailer to consumer, and of packaging residues from consumer to end of life treatment plant. All capital goods were included, except for the supermarket infrastructure.

To allocate co-product burdens, we reasoned with economic values in accordance with Ecoinvent v3 database guidelines, i.e. using 5 economic allocations:

- Kernel (18.7\%) and Crude Palm Oil (81.3\%) (Jungbluth et al., 2007)

- Crude Palm Kernel Oil (92.5\%) and Palm Kernel Cake (7.5\%) (Jungbluth et al., 2007) Palm oil prices may be quite volatile, however the ratios between palm oil and palm kernel oil or kernel meal are quite constant; hence price ratios from 2007 are still relevant for the study.

- Refined Palm Kernel Oil (99.22\%) and Free Fatty Acid (0.78\%) (Blonk Agri-footprint, 2014)

- Cetearyl Alcohol (27.9\%), Methyl Ester (62.38\%) and Glycerol (9.68\%) (unpublished industrial data)

- The part of the cosmetic cream in transport during purchasing (the cosmetic cream price represents $4.66 \%$ of an average shopping basket $)^{1}$

2.2 Production sub-systems and life cycle inventories

\subsubsection{Palm oil production scenarios}

In the current work, the baseline scenario was defined according to main standard industrial practices and alternative scenarios were investigated to assess critical production parameters. These scenarios are further detailed in the following sub-sections.

\footnotetext{
${ }^{1}$ http://www.famillesrurales.org/franche_comte/Upload/LienCMS/dp_obsvprix_janv2015_2_ljv_CMS314.pdf, viewed 29/09/2016
} 
121 We modeled the palm oil production system as a standard industrial production system in Malaysia

122 based on published data. We included all processes and flows from nursery production up to the

123 refined kernel palm oil (RKPO) including background processes. For the baseline scenario, we considered a settled plantation (i.e. without Land Use change) on a mineral soil and conventional industrial transformation processes up to palm oils, notably considering a conventional anaerobic treatment of palm oil mill effluents (POME) in open ponds.

127 Our inventory data for the nursery stage were based on two studies. Data for water consumption, 128 electricity, diesel, plastic (production of polybags in Polyethylene, production of PVC irrigation pipes), 129 fertilizers, pesticides and road transport (seeds, fertilizers and pesticides transport between 130 Malaysian port and nursery) were taken from (Choo et al., 2011; Muhammad et al., 2010). Data for sea transport of field inputs from manufacture site to Malaysian port were taken from Schmidt (2007) (see Table S1, S2 and S3 in supplementary materials).

After the nursery, palm seedlings are transplanted in the oil palm plantation and cultivated for 25 years. The palms are planted at a density of $142 \mathrm{palms} / \mathrm{ha}$ (considering a 5\% loss at replanting). Palm Fresh Fruit Bunches (FFB) are harvested the whole year long starting after the third plantation year. The composition of harvested FFB is: $20 \%$ oil, $25 \%$ nuts ( $5 \%$ kernels, $13 \%$ fibre and $7 \%$ shell) and $23 \%$ of empty fruit bunches (EFB) that are brought back to the field as organic fertilizers. We considered a standard management, including mineral and organic fertilizers, herbicides and field mechanization (Table 1), and an average yearly yield over the whole cycle of $19.16 \mathrm{tFFB} / \mathrm{ha}$.year as detailed in the relevant background publications (Choo et al., 2011; Schmidt, 2007). to limit the formation of Free Fatty Acid (FFA) (Guilbot et al., 2013). Pulp from mesocarp and kernel are then separated. Pulp is pressed with a screw press in order to obtain Crude Palm Oil (CPO). Pressed mesocarp fibers and crushed kernel shells are burnt in the boiler to provide heat and power leading to very limited amount of external energy input to the mill (Choo et al., 2011; Schmidt, 2007). Pressing of kernel allows for the extraction of Crude Kernel Palm Oil (CPKO). Inventory data were taken from various Malaysian studies (Choo et al., 2010; Vijaya et al., 2010). In the baseline scenario, POME, which are composed of sterilization condensates and clarification waters (Parveen et al., 149 2010), were conventionally treated in open anaerobic ponds that emit biogenic methane to the air 150 (Wicke et al., 2008). 
151

152

153

154

155

156

157

158

159

160

161

162

163

164

165

166

167

168

169

170

171

172

173

174

175

176

177

178

179

180

181

After the mill stage, CPKO is chemically refined, implying degumming with acid then cleansing with bleaching earth (Yew et al., 2010). Undesirable components such as FFA are stripped under vacuum in the de-acidification and deodorization steps to finally produce refined palm kernel oil (RPKO) (Guilbot et al., 2013). Energy for CPKO refining process is met by electricity from the grid (Malaysian grid) and fossil-fuel fed boilers. Liquid wastes from the refinery include wastewater and free fatty acid distillate (Table 1).

\subsubsection{Alternative scenarios}

Alternative scenarios were investigated from the farm stage up to the RPKO output, exploring (with or without) 3 critical parameters: deforestation, peat soil oxidation, and methane capture and electricity recovery from POME. Details on the calculation steps for the modified inventories are provided in the following sub-sections.

Within LCA, the impact of deforestation can be included at both inventory and impact assessment levels (the appraisal of the Land Use impact category is described in section 2.3.). In the inventory, deforestation is translated into carbon losses from above and below-ground biomass emitted as $\mathrm{CO}_{2}$. We applied IPCC guidelines Tier1 (2006) to calculate these emissions, considering as previous Land Use a primary forest in Asia (insular) with $350 \times(1+0.37) \mathrm{t}$ biomass/ha using a $37 \%$ ratio of below to above-ground biomass. A palm plantation contains $136 \times(1+0.28)$ t biomass/ha using a $28 \%$ ratio of below to above-ground biomass (IPCC, 2006). Emissions from land use change were implemented in both scenarios with deforestation on mineral and peat soils.

On top of deforestation, converting peat soil to cropland area requires a dense drainage that notably leads to the oxidation of soil organic carbon and finally $\mathrm{CO}_{2}$ emissions. In the inventory, we accounted for annual $\mathrm{CO}_{2}$ emissions due to the peat oxidation, which we further related to an occupation impact (see section 2.3). We relied on the constant emission factor of $40 \mathrm{tCO}_{2} /$ ha.year (EPA, 2014). We did not account for a potential peak of emissions during the first 5-6 years right after the peat drainage started due to a lack of available emission factor and data. We also accounted for $\mathrm{N}_{2} \mathrm{O}$ emissions from peat soil based on the IPCC emission factor (2013). According to IPCC (2013), we did not account for any $\mathrm{CH}_{4}$ emissions specific to changes in peat soil aeration status. No matter whether the palm plantation on peat was established after forest or after replanting, the annual emissions from peat oxidation were considered constant. We did not consider any fluctuations depending on the initial thickness of the peat layer or the drainage depth. These assumptions were further discussed (section 4). 
182

183

184

185

186

187

188

189

190

191

192

193

194

195

196

197

198

199

200

201

202

203

204

205

206

207

208

209

210

211

212

Finally, POME can be treated in different ways. The conventional treatment implies to store POME in open ponds, in which fermentation allows for the degradation of organic compounds in order to reach legal critical levels of Chemical and Biological Oxygen Demands before releasing or spreading of treated effluents. The anaerobic transformation of organic compounds leads to methane emissions, which contribute to global warming. Growing awareness on GHG issues has prompted the industries to seek for new solutions. The development of EFB composting allows for the recycling of raw POME. Moreover, a growing numbers of mills are combined with bioreactors that capture and flare methane from POME treatment with or without energy recovery (EPA, 2012).In our baseline scenario, we considered the conventional treatment and included pond methane emissions (Schmidt, 2007), as well as field emissions after treated POME field application based on IPCC emission factors for organic fertilizers (De Klein et al., 2006). In the alternative scenario, we considered the most interesting treatment alternative up to electricity recovery and substitution of grid electricity.

\subsubsection{Field emission models}

We took into account the emissions related to the use of fertilizers and pesticides. We followed IPCC guidelines (De Klein et al., 2006) in order to calculate the fractions of mineral and organic $\mathrm{N}$-fertilizers emitted to the water $\left(\mathrm{NO}_{3}{ }^{-}\right)$and the air $\left(\mathrm{NH}_{3}\right.$, direct and indirect $\left.\mathrm{N}_{2} \mathrm{O}\right) . \mathrm{NO}_{x}$, emissions were determined according to EMEP/EEA guidelines (EMEP and EEA, 2013). At the nursery stage, it was considered that no leaching could occur through the polybags. We also calculated P-fertilizer losses to the environment based on SALCA-P model (Prasuhn, 2006). For pesticides, we considered that the full rates of pesticides applied ended up in the soil. Fertilizers also contain heavy metals that we considered as stored in the soil (Brockmann et al., 2014).

\subsubsection{Palm-based surfactant production}

\subsubsection{Production of the palm-based cetearyl alcohol}

The processing of RPKO into a palm-based surfactant takes place in Europe. RPKO is transported from Malaysia to France (Marseille) by transoceanic freight ship, then to Germany by train (Guilbot et al., 2013). We considered a transesterification of RPKO with methanol in the presence of sodium hydroxide given the low cost, good yield and easiness to process (Zah and Hischer, 2007). The recovered methanol is recycled in the process. The C-8/14 methyl ester is slit from the C-16/18 methyl ester by distillation separation. The last step is a continuous catalysed hydrogenation of the $\mathrm{C}-16 / 18$ methyl ester under high temperature $\left(250-300^{\circ} \mathrm{C}\right)$ and high hydrogen pressure $(25-35 \mathrm{MPa})$ 
in a fixed bed trickle flow process. The targeted C-16/18 alcohol is finally distilled to reach a purity of more than 95\% (Giraldo et al., 2010) (see Table S4 in supplementary material).

\subsubsection{Production of the complementary wheat-based crystallized D-glucose}

Crystallized D-glucose is needed to produce the palm-based surfactant (128 g per kilogram of APG). The used crystallized D-glucose is derived from wheat starch (Guilbot et al., 2013). For our study, we used an Ecoinvent wheat inventory ("wheat grain $\{F R\}$, wheat production, alloc def") to represent a proxy for the culture of wheat in France. After harvesting, the wheat grains are washed and ground into flour and mixed up with water. The starch and gluten are then separated, and the resulting starch milk is totally hydrolyzed.. The final processing steps involve demineralization, discoloration, concentration by evaporation and crystallization to obtain anhydrous D-glucose (Gerngross, 1999). An amount of $5.6 \mathrm{~g}$ of cultivated wheat provides $3.7 \mathrm{~g}$ of D-glucose, with a transformation energy cost of $1.6 \times 10^{-2} \mathrm{MJ}$ of energy (heat). The output crystallized D-glucose undergoes a Fischer Glucosylation, with sodium hydroxide as neutralization agent. Un-reacted glucose is removed by decantation and centrifugation (Guilbot et al., 2013).

\subsubsection{Final production of the palm-based surfactant}

The last step is the shaping of alkyl polyglucoside (APG) by pearlizing, which was assumed in this study to take place in France (Castres city). We assumed a standard batch of $10.9 \mathrm{t}$ of APG (Guilbot et al., 2013), using $10.5 \mathrm{t}$ of cetearyl alcohol and $1.4 \mathrm{t}$ of crystallized D-glucose (Fig. 1). The supplying of these raw materials is done by lorry $(\sim 1200 \mathrm{~km}$ for the cetearyl alcohol coming from Germany to Castres and $\sim 900 \mathrm{~km}$ for the glucose coming from the North of France to Castres). APG is stored in plastic bags, themselves stored in packaging board of $25 \mathrm{~kg}$. We considered the following packaging: $5.44 \times 10^{-2} \mathrm{~g}$ packaging board and $6.68 \times 10^{-3} \mathrm{~g}$ of plastic film for $1.50 \mathrm{~g}$ of APG. This packaging was recovered in the cosmetic cream plant. We considered a recycling rate of $89 \%$ for packaging board and $20 \%$ for plastic film, the remaining being incinerated (Badey and Lahitte, 2013).

As the APG is solid at room temperature (melting point $\sim 65^{\circ} \mathrm{C}$ ), the entire process is carried out by heating with steam produced by a gas boiler (104 kg of steam per t of APG) (Guilbot et al., 2013). Water input in the whole pearlizing process amounts $1.4 \mathrm{~m}^{3}$ per $\mathrm{t}$ of APG including the used cooling water use that is recycled in a closed circuit system. The final input is dinitrogen, $2.2 \mathrm{~m}^{3}$ per $\mathrm{t}$ of APG, which is used during the entire process in order to prevent coloration with oxygen from the air. Apart from APG, final co-products are: i) glucose muds from the decantation and centrifugation steps ( $\sim 76 \mathrm{~kg}$ per t of APG), which are incinerated in a specific treatment plant (at $\sim 160 \mathrm{~km}$ from the production site); and ii) liquid aqueous effluents ( 14 I per t of APG containing $3000 \mathrm{mg}$ per I of 
245 COD), which are transferred to a wastewater treatment plant (see Table S5 in supplementary 246 materials).

$247 \quad 2.2 .3 \quad$ Moisturizing cream production and use

248

249

250

251

252

253

254

255

256

257

258

259

260

261

262

263

264

265

266

267

268

269

270

271

272

\subsubsection{Production of the cosmetic cream}

The studied cosmetic cream contains $75 \%$ of water, $20 \%$ of an Argan oil phase (not available and hence replaced by "global market for vegetable oil, refined "from ecoinvent"), and $5 \%$ of APG (Guilbot et al., 2013). The emulsification process consists in mixing the three components for about $2 \mathrm{~h}$ at $70^{\circ} \mathrm{C}$ under vigorous agitation, which requires $85 \mathrm{~kg}$ steam and $6 \mathrm{kWh}$ electricity per tonne of cream. Waste are mud (70 kg per t of cream) and liquid wastewater (10 I per t of cream with $3,000 \mathrm{mg}$ COD per I). The final cream is bottled in a $30 \mathrm{~g}$ jar made of $7 \mathrm{~g}$ of HDPE and a tight fitting lid made of $1.79 \mathrm{~g}$ of HDPE. Each jar is packaged in a small cardboard box $(5 \times 5 \times 5 \mathrm{~cm})$ wrapped in a very thin HDPE film $(100 \mu \mathrm{m})$. Our functional unit is the study of 1 jar (Table 2$)$.

\subsubsection{Use and end of life stage}

The final use of the cream is its application on the skin of a consumer. The penetration (dose absorbed through the skin) depends on skin permeability and properties of the cream as saturation solubility. Some authors (Kroes et al., 2007; Williams et al., 2016) defined maximum flux $\left(J_{\max }\right)$ to deal with aspect and classified the dose absorbed during 24haccording it. A cosmetic cream with surfactants, which was the case the present work, enhances skin penetration and promotes dermal absorption of cosmetic ingredients (Williams et al., 2016). Jolliet (Jolliet et al., 2015) considered that after $12 \mathrm{~h}, 96 \%$ of the cream was absorbed. Consequently, in the present work, we assumed that the cream was absorbed for the most part and the quantity of the cream streamed to the wastewater treatment was negligible. This is in accordance with the Sustainability consortium (2013) guidelines where wastewater treatment after the use of a cosmetic product is excluded of the system.

In our study, we did not consider any direct leakage after skin application (Guilbot et al., 2013). However, we considered other potential impacts before and after the cream use, notably the transport steps between production plant and storage (1,000 km by lorry), storage and retailer store (100 km by lorry), from the store up to the consumer house. We also considered the recovery of the jar. 
273 We considered four types of transport in order to buy the cosmetic cream according to the European

274 average: personal car (57\%), walk (24\%), public transport (11\%), and bicycle (8\%) (De La Fuente

275 Layos, 2005).

276 The "public transport" category could be separated into 2 sub categories with the following

277 percentages (European Commission, 2014):

278

279

280

281

282

283

284

285

286

287

288

289

290

291

292

293

294

295

296

297

298

299

- Subway: $18 \%$ (i.e. $2 \%$ from the $11 \%$ public transport)

- Bus: $82 \%$ (i.e. $9 \%$ from the $11 \%$ public transport)

The assumed average roundtrip distance between the customer house and the store was $10 \mathrm{~km}$ (De La Fuente Layos, 2005). We carried out an economic allocation in order to calculate the ratio of the cosmetic cream over the total shopped basket during the purchasing transport.

Wastes were collected to be treated. The cosmetic cream jar with associated packaging consists of $8.79 \mathrm{~g}$ of HDPE, $3.75 \mathrm{~g}$ of cardboard and $1.41 \mathrm{~g}$ of plastic film. If recycling rate for HDPE is very high like for bottles at consumer level, small dirty HDPE containers are commonly not separately collected and can be assimilated to undifferentiated small packaging with a recycled rate of 3\% (BIO Intelligence Service, 2013). In the European context, $65 \%{ }^{2}$ of cardboard and $10 \%$ of plastic film are recycled (BIO Intelligence Service, 2013). The non-recycled parts (97\%, 35\% and 90\% respectively), are incinerated and landfilled according European waste management practices ${ }^{3}$, (49\% and $51 \%$ respectively). These assumptions are further discussed (section 4).

\subsection{Impact characterisation and selected indicators}

We applied ILCD (2011 V1.06) (European Commission, 2012) recommendations regarding the selection of impact characterisation methods. We hence assessed 12 potential midpoint impacts (see Table $\mathbf{6} 6$ in supplementary material).

Concerning the Land Use impact, following ILCD, we applied the "Land Use" indicator (Brandão and Milà i Canals, 2013; Koellner et al., 2013; Milà i Canals et al., 2007). This indicator measures the change in the amount of organic matter in soil ( $30 \mathrm{~cm}$ deep) as a proxy to quantify how the use of a land area may impact the soil properties and functions. This indicator is expressed in $\mathrm{kg} C$ deficit. It integrates the impact due to land transformation and land occupation relatively to a reference state

\footnotetext{
${ }^{2}$ http://ec.europa.eu/eurostat/web/waste/key-waste-streams/packaging viewed 29/09/2016

3 http://ec.europa.eu/eurostat/tgm/refreshTableAction.do?tab=table\&plugin=1\&pcode=tsdpc240\&language=e n viewed 29/09/2016
} 
300

301

302

303

304

305

306

307

308

309

Eq.1

$$
\Delta \operatorname{SOC}\left(\frac{k g_{C}}{m^{2}}\right)=\frac{\frac{1}{2}\left(t_{\text {relax }}-t_{\text {ini }}\right) *\left(S O C_{\text {ini }}-S O C_{\text {end }}\right)}{\left(t_{\text {end }}-t_{\text {ini }}\right)}
$$

310

(without considering any irreversible process). The occupation indicator theoretically includes two compounds. The first one refers to the impact of delaying the restoration of the potential SOC due to land occupation, the second refers to a further actual degradation or improvement in the SOC due to the land occupation. The latter, further referred to as "occupational change", is not yet implemented in ILCD (EC-JRC, 2011). We further refer to "occupational delay" for the currently implemented occupation impact in Land Use indicator. Characterisation factors are calculated based on SOC database from IPCC (2006).

For transformation, the gain or loss of $\mathrm{SOC}$ is calculated according to the following formula (Brandão and Milà i Canals, 2013; Milà i Canals et al., 2007):

\section{Where:}

$S O C_{i n i}=$ Soil Organic Carbon at the initial state

$S O C_{\text {end }}=$ Soil Organic Carbon at the final state

$t_{\text {ini }}=$ Initial time

$t_{\text {end }}=$ Final time

$t_{\text {relax }}=$ Relaxation time (at $t_{\text {relax }}$ SOC has reverted to the level in the reference state)

In the baseline scenario, there is no transformation $\left(S O C_{i n i}=S O C_{\text {end }}=\right.$ palm plantation). In the alternative scenarios, we first calculated the Land Use transformation impact linked to deforestation (i.e. $S O C_{i n i}=$ primary forest on mineral soil; $S O C_{\text {end }}=$ palm plantation on mineral soil). We then also calculated the Land Use impact linked to peat soil cultivation with Land Use change (i.e. $S O C_{i n i}=$ primary forest on peat soil; $S O C_{\text {fin }}=$ palm plantation on peat soil).

For peat soil in Asia, there was no characterisation factor in the Land Use indicator of ILCD methodology. We hence needed to create this soil category in order to take into account the original high carbon stocks in peat soils and potential subsequent effects from the draining and oxidation of peat soil. According to Page et al. (2011), the soil carbon content of a peat soil in Southeast Asia is $55.3 \mathrm{~kg} \mathrm{C} / \mathrm{m}^{2}$ (considering the stock over the first $30 \mathrm{~cm}$ depth with a homogeneous distribution over 
the first $150 \mathrm{~cm})$. We considered this stock to be the potential initial carbon stock $\left(S O C_{\text {ini }}\right)$ and used the soil carbon content of $8.6 \mathrm{~kg} \mathrm{C} / \mathrm{m}^{2}$ as a final stock ( $S O C_{\text {end }}$ ). The latter is the one given for tropical wetland under natural vegetation. We chose this stock as the final one considering that it was too low to refer to a natural undisturbed peat soil under forest.

In our study, we considered a regeneration or relaxation time, $t_{\text {relax }}$, for a used peat soil to recover its initial soil carbon stock, of 1,000 years. This time period corresponded to the highest relaxation time available (i.e. the one considered for sealed land)(Milà I Canals et al., 2007), considering that all potential changes are reversible. According to Milà I Canals (2007), we assumed an initial instantaneous transformation over one year, i.e. $t_{\text {end }}-t_{\text {ini }}=1$.

The calculated characterisation factor for peat soil transformation was finally: $\Delta \mathrm{SOC}=$ $23,350 \mathrm{~kg} \mathrm{C} / \mathrm{m}^{2}$

For occupation, the impact on soil is calculated according to the following formula:

$$
\Delta S O C\left(\frac{k g_{C}}{m^{2}}\right)=\frac{\left(S O C_{\text {pot }}-S O C_{\text {ini }}\right) *\left(t_{\text {relax }}-t_{\text {ini }}\right)}{\left(t_{\text {end }}-t_{\text {ini }}\right)}
$$

Where:

$S O C_{i n i}=$ Soil Organic Carbon at the initial state

$S O C_{p o t}=$ Soil Organic Carbon potential (at the native state)

$t_{\text {ini }}=$ Initial time

$t_{\text {end }}=$ Final time

$t_{\text {relax }}=$ Relaxation time (at $t_{\text {relax }} \mathrm{SOC}$ has reverted to the level in the reference state)

In this formula, according to Milà I Canals (2007), we considered that $t_{\text {relax }}=t_{\text {end }}$

The occupational delay impact is a constant annual carbon deficit due to the lack in carbon stock compared to potential natural state. Result is valid for each year without specification on the soil type. For occupation of peat soil in Asia, we took $S O C_{p o t}=55.3 \mathrm{kgC} / \mathrm{m}^{2}$, and $S O C_{i n i}=8.6 \mathrm{kgC} / \mathrm{m}^{2}$, i.e. $\Delta \mathrm{SOC}=46.7 \mathrm{~kg} \mathrm{C} / \mathrm{m}^{2}$.year. For occupation of mineral soil, we use the ILCD default characterisation factor for "permanent crop Land Use occupation", without specification on the soil type, i.e. $\Delta$ SOC $=$ $4 \mathrm{~kg} \mathrm{C} / \mathrm{m}^{2}$.year. 
In addition to this occupational delay impact factor, we also added an actual annual degradation, i.e. occupational change, in soil carbon content due to the draining and oxidation of peat soil. The oxidation of peat soil causes high $\mathrm{CO}_{2}$ emissions, which we have included in the life cycle inventory in terms of greenhouse gas emissions contributing to the Climate Change impact (see section 2.2.1.2). In order to be consistent and to take into account this soil organic carbon loss for the Land Use, we converted this $\mathrm{CO}_{2}$ inventory flow into an annual carbon stock change for Land Use impact category (was converted into $1.1 \mathrm{~kg} \mathrm{C} / \mathrm{m}^{2}$.year) (section 2.2.1.2).

\section{Results}

3.1. Baseline scenario: continuous palm plantation on mineral soil

We performed a contribution analysis of the various production stages including the refined palm kernel oil (RKPO), the rest of the cosmetic cream compound production and processing, the production of the packaging, the transport to retailer and consumer, and the consumer waste management (Fig.2). We notably wanted to assess the relative contributions of agricultural stage (with a focus on palm oil production) and other industrial and logistical stages.

The contribution of each stage group to the total impacts varied with the impact category. Most impacting stages were transport to retailer and consumer, packaging and cosmetic cream. Transport to retailer and consumer was the main contributing process (largest for 11 out of 15 impacts indictors, $\min =12 \%$ for lonising Radiation Human Health, $\max =82 \%$ for Mineral, Fossil and Renewable Resources Depletion). The high impact in terms of Mineral, Fossil and Renewable Resource Depletion was due to fossil fuel use in engines. Packaging production was also a significant contributing process (largest for 2 out of 15 impacts indicators, $\min =4 \%$ for Mineral, Fossil and Renewable Resource Depletion, $\max =82 \%$ for Ionising Radiation Human Health). The high impacts were notably related to the energy input, especially the electricity use from the French mix that relies greatly on nuclear electricity leading to a high contribution on Ionising Radiation Human Health. The total contribution of the production of the cosmetic cream itself, i.e. the production of refined palm kernel oil and other compounds and further transformations and assemblages up to the cream without its packaging, represented a high impact ( $\min =6 \%$ for lonising Radiation Human Health, $\max =58 \%$ for Land Use) of the impacts. Main contributing stages in the cosmetic cream production were the industrial transformation processes and the production of other vegetable oil, followed by RPKO and the wheat derivative. Cosmetic cream production, RPKO apart, had a nonnegligible impact ( $\min =6 \%$ for lonising Radiation Human Health, $\max =54 \%$ for Land Use). The high 
impact for Land Use was related to the use other vegetable oil besides RPKO. The RPKO production in the baseline scenario, which represented a non-negligible agricultural input on a feedstock mass basis (1.9 g RPKO for $0.3 \mathrm{~g}$ wheat and $6 \mathrm{~g}$ of other oils, i.e. $20 \%$ of the $30 \mathrm{~g}$ cream ), only had limited impacts ( $\min =0.3 \%$ for lonising Radiation Human Health, $\max =12 \%$ for Marine Eutrophication). The consumer waste management had a non-negligible impact in terms of avoided impact due to material recycling notably regarding Ionizing Radiation Ecosystems, where it led to a $32 \%$ reduction of the global impact.

We further investigated the process contributions within the RPKO production stage (Fig. 3). In the baseline scenario, the impacts of RPKO production were driven by the fresh fruit bunch (FFB) production in the field and the palm oil processing. The palm oil mill effluent (POME) treatment essentially contributed to the Climate Change impact (53\%) due to the release of methane during anaerobic treatment in open ponds. FFB production had the largest impact overall $(\mathrm{min}=34 \%$ for Climate Change, $\max =96 \%$ for Marine Eutrophication). This high impact was notably due to the use of synthetic mineral fertilizers greatly contributing to Climate Change, Photochemical Ozone Formation, Acidification and Eutrophication impact categories. Crude palm oil (CPO) extraction, i.e. fruit production apart, also had a high impact $(\min =1 \%$ for Land Use, $\max =60 \%$ for Climate Change). CPO has a high impact for Particulate Matter mostly came from power central (boiler) and to a lesser extent from the plant construction. Further contributions from other energy and chemical uses (refinery step), as well as input and fruit transport to the mill, had low impacts.

\subsection{Influences of deforestation, peat soil oxidation, and POME treatment}

We investigated deeper the influence on the overall cosmetic cream impacts of the palm plantation establishment and the palm oil mill effluent treatment. The parameters tested in the alternative scenarios (see section 2.2.1.2) were the following:

- The previous Land Use: primary forest, i.e. deforestation, or palm cultivation, i.e. continuous agricultural land use

- Soil type: mineral or peat soils

- The treatment of POME: conventional treatment or methane capture and electricity recovery.

Deforestation and peat soil transformation and occupation were translated i) in the life cycle inventory as GHG emissions, and ii) in soil organic carbon changes embedded in the Land Use impact. Hence, these two parameters only influenced two impact categories, i.e. Climate Change and Land 
Use (Fig. 4). On Climate Change indicator, deforestation caused an increase of about $9 \%$ in the cosmetic cream final impact (i.e. $+282 \%$ in the RPKO impact), peat soil occupational change (i.e. annual degradation of carbon stock and related $\mathrm{CO}_{2}$ emissions) caused an even greater increase of $16 \%$ over the whole cosmetic cream life cycle (i.e. $+46 \%$ for the RPKO). On Land Use indicator, deforestation caused an increase of $3 \%$, peat soil occupational delay (i.e. both the annual degradation and the annual cost for delaying the relaxation to natural stock) and transformation caused impact increases of $41 \%$ and $938 \%$, respectively. The influence of peat soil transformation and occupational delay was tremendous and in particular even much higher than that of deforestation. These high increases corresponded to a variation of $+917 \%$ for peat soil occupational delay and $+20,904 \%$ for peat soil transformation when focusing on the RPKO impacts.

Methane capture and conversion to electricity represented a low decrease in environmental impact ( $\min =-0.1 \%$ for lonizing Radiation Human Health, $\max =-3 \%$ for Marine Eutrophication). The gain provided by the improved treatment of POME was very low but consistent across all impact categories. Focusing on RPKO production stage, POME improved treatment allowed a low decrease. So, at the agricultural scale, POME improved treatment in order to produce electricity remained interesting. At the cream final product scale, the gain provided remained negligible. However, compared to deforestation and peat soil transformation and occupation, improved POME treatment had a general, albeit small, positive influence on all impact categories.

\section{Discussion}

In the baseline scenario, which corresponded to a standard industrial palm production system in Malaysia with no land use change, we could observe an impact of the palm kernel oil production and refinery on the overall life cycle impact of the cosmetic cream. In this context, the contribution of refined palm kernel oil was not critical with regard to the other process stages along the whole lifecycle of the cosmetic cream. Moreover, palm kernel oil extraction and refinery processes were less energy intensive (particularly in terms of fossil energy use) than most of the other up- and downstream processes.

In comparison with the baseline economic allocation approach, using mass allocation ratios (except at purchase stage due to lack of data for mass of shopping basket), environmental impacts would have been lower ( $\min =-0.4 \%$ for lonizing Radiation; $\max =-15 \%$ for Marine Eutrophication). Mass allocation ratios lowered RPKO impacts given the higher price per mass unit compared to refined palm oil. The contribution of RPKO production to the final cream impact was very low. Besides 
reduction in RPKO impacts with mass allocation ratio, the contributions of other cream life cycle stages were not influenced by the change in allocation ratios.

Within the whole life-cycle of the cosmetic cream, the more impacting stages were packaging and transport. The primary data from the industrial partner allowed for a refined site-specific modelling of the industrial phase. However, some assumptions were still needed as well as the use of some secondary data from Ecoinvent v.3 database for some upstream background processes. We also modelled average current practices in term of transportation means and distances. More specific transport strategies might be explored to reduce the overall impacts but would need to be assessed on a case-by-case basis. Transport apart, the main remaining problem is the packaging which influenced significantly the final cream impacts, we looked at alternative scenarios for the end of life of the packaging (see Fig S1 in supplementary materials). When the HDPE packaging was entirely recycled, the total cream impacts were reduced ( $\min =0 \%$ for Ozone Depletion; $\max =-25 \%$ for lonizing Radiation), with a packaging impact (production + end of life management) contribution slightly decreased. Further complementary investigations might also be needed to check whether the assumption of the cream absorption with negligible washing out (Guilbot et al., 2013) may have an influence on the final results.

In the alternative scenarios, the RPKO contribution became much more critical for two impact categories, i.e. Climate Change and Land Use. The annual $\mathrm{CO}_{2}$ emissions and the cumulated soil organic carbon depletion due to the draining and oxidation of the peat soil were the most influential parameters over all. Impact of peat soil drainage and oxidation would be even higher considering the former IPCC coefficient for wetland $\mathrm{N}_{2} \mathrm{O}$ emissions (2006), i.e. $+10 \%$ in the RPKO Climate Change impact, or lower with another reference for $\mathrm{CO}_{2}$ emissions (Hooijer et al., 2010), i.e. -18\% in the RPKO Climate Change impact. This emphasises the need for further research work and consensus finding on guidelines and coefficients to assess the environmental impact of peat soil conversion. We adapted some coefficients and stocks found in the literature and proposed to include some part of the occupation impact, which is usually considered as negligible. However, more needs to be done. Concerning peat soil conversion, several factors in particular would need to be further addressed, e.g. the flush emissions right after opening and drainage start, the irreversible impact due to acute subsidence, the methane emissions from the drains or the indirect impacts at the watershed level, etc. From an environmental point of view, though, these estimate on Climate Change and Land Use impacts, albeit incomplete and perfectible, already highlight the prohibitive impact of peat soil conversion to agricultural uses where dense drainage is mandatory. 
Our study aimed at providing a comprehensive LCA of a bio-sourced product, while focusing on the relative importance of the agricultural stage and production conditions over the whole supply chain. Further investigations would be necessary in order to better model potential discrepancies in agroecological performances between oil palm productions on mineral or peat soils, e.g. potential variations in crop cycle length, yields, disease pressure, and pesticide or fertilizer managements.

\section{Conclusion}

This study dealt with environmental impacts of a cosmetic cream, which contained palm kernel oilbased as surfactant, from feedstock production to end of life management. It gave a precise picture of main impact contributors over the whole life-cycle of a bio-based cosmetic cream. It turned out that the transport from the retailer to the customer had the highest impact (highest for 11 out of 15 impacts indictors, $\min =12 \%$ for lonising Radiation Human Health, $\max =82 \%$ for Mineral, Fossil and Renewable Resource Depletion). It was mainly caused by the use of petrol. The packaging had also a high impact $(2$ out of $15, \min =4 \%$ for Mineral, Fossil and Renewable Resource Depletion, $\max =82 \%$ for lonising Radiation Human Health). Agricultural phase in order to obtain RPKO had a small impact contribution ( $\min =0.3 \%$ for lonising Radiation Human Health, $\max =12 \%$ for Marine Eutrophication). The rests of the impacts were due to chemical step ( $\mathrm{min}=6 \%$ for lonising Radiation Human Health, $\max =54 \%$ for Land Use) and end of life management ( $\min =-32 \%, \max =11 \%$ ).

Many parameters could influence the palm oil production (i.e. RPKO impact contribution) and we investigated three of them: the previous land use, soil type and POME management. Mainly two impacts indicators were concerned in the alternative scenarios: Climate Change and Land Use with an increase of $25 \%$ and $1,528 \%$, respectively, compared to the baseline scenario. On Climate Change, $9 \%$ were caused by deforestation and $16 \%$ by peat soil transformation and use. On Land Use, $938 \%$ were caused by peat soil transformation, $41 \%$ by peat soil use and occupational delay, and $3 \%$ by deforestation. Within the complete cream life-cycle, peat soil transformation and cultivation had the highest impact, while POME management was negligible.

An eco-design of the cosmetic cream could reduce its environmental impact considering some improvements at several stages. One of the key aspects was the packaging, where lower mass could reduce production and transportation impacts. Ecodesign would also require the integration of good farming practices, mainly concerning the previous land use and the type of soil, avoiding peat soil use. Through the example of a palm oil based cosmetic cream, this study showed the interest of a whole approach to bring face-to-face agricultural productions, transformations and use of products.

\section{References}


Achten, W.M.J., Vandenbempt, P., Almeida, J., Mathijs, E., Muys, B., 2010. Life Cycle Assessment of a Palm Oil System with Simultaneous Production of Biodiesel and Cooking Oil in Cameroon. Environ. Sci. Technol. 44, 4809-4815. doi:10.1021/es100067p

ADEME, BIO Intelligence Service, 2010. Analyse de Cycle de Vie appliquées aux biocarburants de première génération consommés en France.

Angarita, E.E.Y., Silva Lora, E.E., da Costa, R.E., Torres, E.A., 2009. The energy balance in the Palm OilDerived Methyl Ester (PME) life cycle for the cases in Brazil and Colombia. Renew. Energy 34, 2905-2913. doi:10.1016/j.renene.2009.05.007

Arvidsson, R., Persson, S., Fröling, M., Svanström, M., 2011. Life cycle assessment of hydrotreated vegetable oil from rape, oil palm and Jatropha. J. Clean. Prod. 19, 129-137. doi:10.1016/j.jclepro.2010.02.008

Badey, L., Lahitte, N., 2013. Guide de méthodologie simplifiée pour la réalisation des ACV dans le cadre de la mise à disposition de l' information environnementale des huiles végétales.

BIO Intelligence Service, 2013. Study on an increased mechanical recycling target for plastics, Final report prepared for Plastics Recyclers Europe, BIO Intelligence Service for Plastics Recyclers Europe.

Blonk Agri-footprint, 2014. Agri-footprint Methodology and Basic Principles.

Boonrod, B., Prapainainar, C., Narataruksa, P., Kantama, A., Saibautrong, W., Sudsakorn, K., Mungcharoen, T., Prapainainar, P., 2016. Evaluating the environmental impacts of biohydrogenated diesel production from palm oil and fatty acid methyl ester through life cycle assessment. J. Clean. Prod. 1-12. doi:10.1016/j.jclepro.2016.07.128

Brandão, M., Milà i Canals, L., 2013. Global characterisation factors to assess land use impacts on biotic production. Int. J. Life Cycle Assess. 18, 1243-1252. doi:10.1007/s11367-012-0381-3

Brockmann, D., Hanhoun, M., Négri, O., Hélias, A., 2014. Environmental assessment of nutrient recycling from biological pig slurry treatment--impact of fertilizer substitution and field emissions. Bioresour. Technol. 163, 270-9. doi:10.1016/j.biortech.2014.04.032

Chavalparit, O., Rulkens, W.H., Mol, A.P.J., Khaodhair, S., 2006. OPTIONS FOR ENVIRONMENTAL SUSTAINABILITY OF THE CRUDE PALM OIL INDUSTRY IN THAILAND THROUGH ENHANCEMENT OF INDUSTRIAL ECOSYSTEMS. Environ. Dev. Sustain. 8, 271-287. doi:10.1007/s10668-005-9018- 
538

539

540

541

542

543

544

545

546

547

548

549

550

551

552

553

554

555

556

557

558

559

560

561

562

Choo, Y.M., Muhamad, H., Hashim, Z., Subramaniam, V., Puah, C.W., Tan, Y., 2011. Determination of GHG contributions by subsystems in the oil palm supply chain using the LCA approach. Int. J. Life Cycle Assess. 16, 669-681. doi:10.1007/s11367-011-0303-9

Choo, Y.M., Puah, C.W., Yew, A.T., Vijaya, S., Zulkifli, H., Halimah, M., 2010. Part 3a: Life cycle assessment of the production of crude palm kernel oil. J. oil palm Res. 22, 904-912.

Chuchuoy, K., Paengjuntuek, W., Usubharatana, P., Phungrassami, H., 2009. Preliminary study of Thailand carbon reduction label : a case study of crude palm oil production. Eur. J. Sci. Res. 34, 252-259.

De Klein, C., Novoa, R.S., Ogle, S., Smith, K.A., Rochette, P., Wirth, T.C., 2006. Chapter 11 N2O emissions from managed soils, and $\mathrm{CO} 2$ emissions from lime and urea application 1-54.

De La Fuente Layos, L.A., 2005. Mobilité des passagers à courte distance en Europe.

Drösler, M., Verchot, L., Freibauer, A., Pan, G., 2013. Chapter 2 drained inland organic soils 1-79.

EC-JRC, 2011. International Reference Life Cycle Data System (ILCD) Handbook: Recommendations for Life Cycle Impact Assessment in the European context EUR 24571 EN - 2011, First Edit. ed. Publications Office of the European Union, Luxembourg. doi:10.278/33030

EMEP, EEA, 2013. Air pollutant emission inventory guidebook. doi:10.2800/92722

EPA, 2012. Final Directive on Palm Oil. RFS2. Federal Register / Vol. 77, No. 18.

European Commission, 2012. Characterisation factors of the ILCD Recommended Life Cycle Impact Assessment methods. doi:10.2788/60825

European Commission, E., 2014. EU Transport in Figures.Statistical Pocketbook 2014. doi:10.2832/63317

European Palm Oil Alliance, 2015. Palm Oil Consumption [WWW Document]. URL http://www.palmoilandfood.eu/en/palm-oil-consumption

Fargione, J., Hill, J., Tilman, D., Polasky, S., Hawthorne, P., 2008. Land Clearing and the Biofuel Carbon Debt. Science (80-. ). 319, 1235-1239. 
Farrel, A.E., Plevin, R.J., Turner, B.T., Jones, A.D., O’Hare, M., Kammen, D.M., 2006. Ethanol Can Contribute to Energy and Environmental Goals. Science (80-. ). 311, 506-509.

Gerngross, T.U., 1999. Can Biotechnology move us toward a sustainable society? Nat. Biotechnol. 17, 541-544.

Gibbs, H.K., Johnston, M., Foley, J. a, Holloway, T., Monfreda, C., Ramankutty, N., Zaks, D., 2008. Carbon payback times for crop-based biofuel expansion in the tropics: the effects of changing yield and technology. Environ. Res. Lett. 3, 34001. doi:10.1088/1748-9326/3/3/034001

Giraldo, L., Camargo, G., Tirano, J., Moreno-Piraján, J.C., 2010. Synthesis of Fatty Alcohols from Oil Palm Using a Catalyst of Ni-Cu Supported onto Zeolite. E-Journal Chem. 7, 1138-1147. doi:10.1155/2010/439801

Gnansounou, E., Dauriat, A., Villegas, J., Panichelli, L., 2009. Life cycle assessment of biofuels: Energy and greenhouse gas balances. Bioresour. Technol. 100, 4919-4930. doi:10.1016/j.biortech.2009.05.067

Guilbot, J., Kerverdo, S., Milius, A., Escola, R., Pomrehn, F., 2013. Life cycle assessment of surfactants: the case of an alkyl polyglucoside used as a self emulsifier in cosmetics. Green Chem. 15, 3337. doi:10.1039/c3gc41338a

Harsono, S.S., Prochnow, A., Grundmann, P., Hansen, A., Hallmann, C., 2012. Energy balances and greenhouse gas emissions of palm oil biodiesel in Indonesia. GCB Bioenergy 4, 213-228. doi:10.1111/j.1757-1707.2011.01118.x

The sustainability consortium, 2013. Life Cycle Impact Study of Leave-on Skin Care Products. https://www.sustainabilityconsortium.org/hpc/

Hooijer, A., Page, S., Canadell, J.G., Silvius, M., Kwadijk, J., Wösten, H., Jauhiainen, J., 2010. Current and future $\mathrm{CO}_{2}$ emissions from drained peatlands in Southeast Asia. Biogeosciences 7, 15051514. doi:10.5194/bg-7-1505-2010

Hutchings, N., Webb, J., Amon, B., 2013. EMEP/EEA air pollutant emission inventory guidebook 2013 - Crop production and agricultural soil.

Intergovernmental Panel on Climate Change, 2006. Volume 4 Agriculture, Forestry and Other Land Use. 
591

592

593

594

595

596

597

598

599

600

601

602

603

604

605

606

607

608

609

610

611

612

613

614

615

616

617

618

619

Jolliet, O., Ernstoff, A.S., Csiszar, S.A., Fantke, P., 2015. Defining Product Intake Fraction to Quantify and Compare Exposure to Consumer Products. Environ. Sci. Technol. 49, 8924-8931. doi:10.1021/acs.est.5b01083

JRC, EUCAR, CONCAWE, 2008. Well-to-Wheels study. Version 3, year 2008.

Jungbluth, N., Chudacoff, M., Dauriat, A., Dinkel, F., Doka, G., Emmenegger, M.F., Gnansounou, E., Kljun, N., Schleiss, K., Spielmann, M., Stettler, C., Sutter, J., 2007. Life Cycle Inventories of Bioenergy. ecoinvent report No. 17, Ecoinvent. Dübendorf.

Koellner, T., de Baan, L., Beck, T., Brandão, M., Civit, B., Goedkoop, M., Margni, M., i Canals, L.M., Müller-Wenk, R., Weidema, B., Wittstock, B., 2013. Principles for life cycle inventories of land use on a global scale. Int. J. Life Cycle Assess. 18, 1203-1215. doi:10.1007/s11367-012-0392-0

Kroes, R., Renwick, A.G., Feron, V., Galli, C.L., Gibney, M., Greim, H., Guy, R.H., Lhuguenot, J.C., van de Sandt, J.J.M., 2007. Application of the threshold of toxicological concern (TTC) to the safety evaluation of cosmetic ingredients. Food Chem. Toxicol. 45, 2533-2562. doi:10.1016/j.fct.2007.06.021

Lodén, M., 2012. Effect of moisturizers on epidermal barrier function. Clin. Dermatol. 30, 286-296. doi:10.1016/j.clindermatol.2011.08.015

Milà i Canals, L., Bauer, C., Depestele, J., Dubreuil, A., Freiermuth Knuchel, R., Gaillard, G., Michelsen, O., Müller-Wenk, R., Rydgren, B., 2007. Key Elements in a Framework for Land Use Impact Assessment Within LCA (11 pp). Int. J. Life Cycle Assess. 12, 5-15. doi:10.1065/lca2006.05.250

Milà I Canals, L., Muñoz, I., McLaren, S., Miguel, B., 2007. LCA Methodology and Modelling Considerations for Vegetable production and Consumption. CES Working Papers 02/07. United Kingdom, Cent. Environ. Strateg. Univ. Surrey 46.

Muhammad, H., Hashim, Z., Subramaniam, V., Tan, Y. a, Wei, P.C., Let, C.C., May, C.Y., 2010. Life Cycle Assessment of Oil Palm Seedling Production (Part 1). J. Oil Palm Res. 22, 878-886.

Nemecek, T., Schnetzer, J., 2012. Methods of assessment of direct field emissions for LCls of agricultural production systems 0 .

Nilsson, K., Flysjö, A., Davis, J., Sim, S., Unger, N., Bell, S., 2010. Comparative life cycle assessment of margarine and butter consumed in the UK, Germany and France. Int. J. Life Cycle Assess. 15, 916-926. doi:10.1007/s11367-010-0220-3 Cleaner Production, 145, 348-360. , DOI : 10.1016/j.jclepro.2017.01.042 
620

621

622

623

624

625

626

627

628

629

630

631

632

633

634

635

636

637

638

639

640

641

642

643

644

645

646

647

Page, S.E., Rieley, J.O., Banks, C.J., 2011. Global and regional importance of the tropical peatland carbon pool. Glob. Chang. Biol. 17, 798-818. doi:10.1111/j.1365-2486.2010.02279.x

Papong, S., Chom-In, T., Noksa-nga, S., Malakul, P., 2010. Life cycle energy efficiency and potentials of biodiesel production from palm oil in Thailand. Energy Policy 38, 226-233. doi:10.1016/j.enpol.2009.09.009

Parveen, F.R., Rajeev, P.S., Hakimi, I., Norizan, E., 2010. Review of current palm oil mill effluent (POME) treatment methods: Vermicomposting as a sustainable practice. World Appl. Sci. ... 11, 70-81.

Pleanjai, S., Gheewala, S.H., Garivait, S., 2009. Greenhouse gas emissions from the production and use of palm methyl ester in Thailand. Int. J. Glob. Warm. 1, 418. doi:10.1504/IJGW.2009.029213

Prasuhn, V., 2006. Erfassung der PO 4 -Austräge für die Ökobilanzierung. SALCA-Phosphor, in: Agroscope FAL Reckenholz. Zürich.

Reijnders, L., Huijbregts, M.A.J., 2008. Palm oil and the emission of carbon-based greenhouse gases. J. Clean. Prod. 16, 477-482. doi:10.1016/j.jclepro.2006.07.054

Rival, A., Levang, P., 2014. Palms of controversies Oil palm and development challenges.

Schmidt, J.H., 2007. Life cycle assessment of rapeseed oil and palm oil.

Secchi, M., Castellani, V., Collina, E., Mirabella, N., Sala, S., 2016. Assessing eco-innovations in green chemistry: Life Cycle Assessment (LCA) of a cosmetic product with a bio-based ingredient. J. Clean. Prod. 129, 269-281. doi:10.1016/j.jclepro.2016.04.073

Vijaya, S., Choo, Y.M., Halimah, M., Zulkifli, H., Tan, Y.A., Puach, C.W., 2010. LIFE CYCLE ASSESSMENT OF THE PRODUCTION OF CRUDE PALM OIL ( Part 3 ) 22, 895-903.

Wicke, B., Dornburg, V., Junginger, M., Faaij, A., 2008. Different palm oil production systems for energy purposes and their greenhouse gas implications. Biomass and Bioenergy 32, 1322-1337. doi:10.1016/j.biombioe.2008.04.001

Williams, F.M., Rothe, H., Barrett, G., Chiodini, A., Whyte, J., Cronin, M.T.D., Monteiro-Riviere, N.A., Plautz, J., Roper, C., Westerhout, J., Yang, C., Guy, R.H., 2016. Assessing the safety of cosmetic chemicals: Consideration of a flux decision tree to predict dermally delivered systemic dose for comparison with oral TTC (Threshold of Toxicological Concern). Regul. Toxicol. Pharmacol. 76, Cleaner Production, 145, 348-360. , DOI : 10.1016/j.jclepro.2017.01.042 
649 Yew, A.T., Halimah, M., Zulkifli, H., Vijaya, S., Puah, C.W., Chong, C.L., Maah, N., Choo, Y.M., 2010. Life 650 Cycle Assessment of refined palm oil production and fractionation (part 4) 22, 913-926.

651 Yusoff, S., Hansen, S.B., 2007. Feasibility Study of Performing an Life Cycle Assessment on Crude Palm 652 Oil Production in Malaysia. Int. J. Life Cycle Assess. 12, 50-58.

653 Zah, R., Hischer, R., 2007. Life cycle inventories of detergents, Report n¹2, Ecoinvent. ed.

654 Zulkifli, H., Halimah, M., Mohd Basri, W., Choo, Y.M., 2009. Life cycle assessment for FFB production. 655 PIPOC 2009 Palm Oil - Balanc. Ecol. with Econ. 6.

656

657

658

659 


\section{ACCEPTED MANUSCRIPT}

Table 1: Life Cycle Inventory for the production of $23.57 \mathrm{~kg}$ of RPKO (from 1000kg of FFB)

\begin{tabular}{|c|c|c|c|c|c|}
\hline & Unit & FFB & Kernels & CPKO & RPKO \\
\hline \multicolumn{6}{|l|}{ Output products } \\
\hline FFB & $\mathrm{kg}$ & $1,000^{b}$ & & & \\
\hline Kernels & $\mathrm{kg}$ & & $53.2^{b}$ & & \\
\hline CPKO & $\mathrm{kg}$ & & & $23.88^{b}$ & \\
\hline RPKO & $\mathrm{kg}$ & & & & $23.57^{b}$ \\
\hline $\mathrm{CPO}$ & $\mathrm{kg}$ & & $199.8^{b}$ & & \\
\hline EFB & $\mathrm{kg}$ & & $225^{\mathrm{b}}$ & & P \\
\hline POME & & & $672.5^{b}$ & & 0 \\
\hline Palm kernel cake & $\mathrm{kg}$ & & & $27.72^{b}$ & 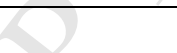 \\
\hline Free Fatty Acid & $\mathrm{kg}$ & & & & $0.24^{b}$ \\
\hline Input & & & & $\infty$ & $y$ \\
\hline Soil transformation & $\mathrm{m}^{2}$ & $20.9^{h}$ & & 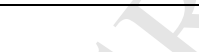 & 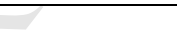 \\
\hline Soil occupation & $m^{2}$ year & $521.9^{h}$ & & 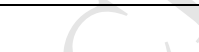 & \\
\hline \multicolumn{6}{|l|}{ Energy use } \\
\hline $\begin{array}{l}\text { Diesel : agriculture } \\
\text { machinery }\end{array}$ & $L$ & $2.37^{\mathrm{a}}$ & $0.57^{b}$ & 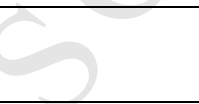 & \\
\hline $\begin{array}{l}\text { Electricity from the } \\
\text { grid }\end{array}$ & MJ & & $0.8^{b}$ & $10.03^{b}$ & $2.99^{b}$ \\
\hline Electricity produced & $\mathrm{MJ}$ & & $31^{b}$ & & \\
\hline Heat (steam) & MJ & & 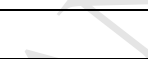 & & $7.73^{b}$ \\
\hline Material use & & & 2 & & \\
\hline Water & $\mathrm{L}$ & & $1,300^{b}$ & $9.55^{b}$ & $16.5^{b}$ \\
\hline Oil palm seedling & Transplant & $0.33^{\mathrm{a}}$ & $8 y$ & & \\
\hline Amonium sulfate & $\mathrm{kg}$ & $8.05^{\mathrm{a}}$ & & & \\
\hline Urea & $\mathrm{kg}$ & $0.41^{\mathrm{a}}$ & & & \\
\hline Ammonium nitrate & $\mathrm{kg}$ & $0.76^{\mathrm{a}}$ & & & \\
\hline Ammonium chloride & $\mathrm{kg}$ & $0.72^{\mathrm{a}}$ & & & \\
\hline $\mathrm{N}$ Nitrogen fertiliser, as & $\mathrm{kg}$ & $3.49^{a}$ & & & \\
\hline $\begin{array}{l}\text { Potassium chloride, as } \\
\mathrm{K}_{2} \mathrm{O}\end{array}$ & $\mathrm{kg}$ & $11.60^{\mathrm{a}}$ & & & \\
\hline $\begin{array}{l}\text { Potassium fertiliser, as } \\
\mathrm{K}_{2} \mathrm{O}\end{array}$ & $\mathrm{kg}$ & $4.50^{a}$ & & & \\
\hline $\begin{array}{l}\text { Phosphate rock, as } \\
\text { P2O5 }\end{array}$ & $\mathrm{kg}$ & $6.55^{a}$ & & & \\
\hline Phosphate fertiliser, as & $\mathrm{kg}$ & $0.64^{a}$ & & & \\
\hline P2O5 & & & & & \\
\hline Glyphosate & $\mathrm{kg}$ & $0.34^{\mathrm{a}}$ & & & \\
\hline $\begin{array}{l}\text { [Sufonyl]urea } \\
\text { compounds }\end{array}$ & $\mathrm{kg}$ & $0.15^{\mathrm{a}}$ & & & \\
\hline $\begin{array}{l}\text { Bipyridylium } \\
\text { compounds }\end{array}$ & $\mathrm{kg}$ & $0.10^{\mathrm{a}}$ & & & \\
\hline Pyretroid compounds & $\mathrm{kg}$ & $2.15 \times 10^{-2 a}$ & & & \\
\hline $\begin{array}{l}\text { Organophosphorus } \\
\text { compounds }\end{array}$ & $\mathrm{kg}$ & $6.40 \times 10^{-2 a}$ & & & \\
\hline Dimethylamine & $\mathrm{kg}$ & $3.10 \times 10^{-2 a}$ & & & \\
\hline Pesticide unspecified & $\mathrm{kg}$ & $2.13^{a}$ & & & \\
\hline Phosphoric acid & $\mathrm{kg}$ & & & & $5.89 \times 10^{-3 b}$ \\
\hline
\end{tabular}


ACCEPTED MANUSCRIPT

\begin{tabular}{|c|c|c|c|c|c|}
\hline $\mathrm{NaOH}$ & $\mathrm{kg}$ & & & & $6.83 \times 10^{-2 b}$ \\
\hline Bleaching earth & $\mathrm{kg}$ & & & & $1.06 \times 10^{-1 b}$ \\
\hline \multicolumn{6}{|l|}{ Transport } \\
\hline FFB to mill, lorry & $\mathrm{tkm}$ & 50 & & & \\
\hline $\begin{array}{l}\text { Fertilizer from plant to } \\
\text { port, ship }\end{array}$ & $\mathrm{tkm}$ & $171.95^{b}$ & & & \\
\hline $\begin{array}{l}\text { Pesticides from plant } \\
\text { to port, ship }\end{array}$ & $\mathrm{tkm}$ & $14.14^{b}$ & & & \\
\hline $\begin{array}{l}\text { Fertilizer from port to } \\
\text { plantation, lorry }\end{array}$ & $\mathrm{tkm}$ & $5.10^{a}$ & & & \\
\hline $\begin{array}{l}\text { Pesticides from port to } \\
\text { plantation, lorry }\end{array}$ & $\mathrm{tkm}$ & $0.15^{a}$ & & & \\
\hline $\begin{array}{l}\text { Raw material and } \\
\text { ancillaries, lorry }\end{array}$ & $\mathrm{tkm}$ & & $0.1^{b}$ & & \\
\hline Kernel, lorry & $\mathrm{tkm}$ & & & $4.2^{b}$ & \\
\hline Palm kernel cake, lorry & $\mathrm{tkm}$ & & & $1.1^{b}$ & \\
\hline Phosphoric acid & $\mathrm{tkm}$ & & & $C_{2}$ & $5.89 \times 10^{-3 b}$ \\
\hline $\mathrm{NaOH}$ & $\mathrm{tkm}$ & & $\alpha$ & 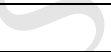 & $6.84 \times 10^{-2 b}$ \\
\hline Bleaching earth & $\mathrm{tkm}$ & & & 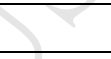 & $1.06 \times 10^{-1 b}$ \\
\hline Diesel & $\mathrm{tkm}$ & & $\mathrm{A}$ & 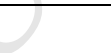 & $3.77 \times 10^{-2 b}$ \\
\hline Fodder fat & $\mathrm{tkm}$ & & 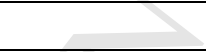 & & $4.71 \times 10^{-2 b}$ \\
\hline \multicolumn{6}{|l|}{ Emissions to air } \\
\hline $\mathrm{CO}_{2}$ & $\mathrm{~kg}$ & 0 & 28 & & \\
\hline $\begin{array}{l}\mathrm{CO}_{2} \text { land } \\
\text { transformation }\end{array}$ & $\mathrm{kg}$ & 0 & & & \\
\hline $\mathrm{NH}_{3}$ & $\mathrm{~kg}$ & $4.50 \times 10^{-1 c}$ & $4.24 \times 10^{-2 b}$ & & \\
\hline $\mathrm{N}_{2} \mathrm{O}$ & $\mathrm{kg}$ & $7.57 \times 10^{-2 b, c}$ & $6.81 \times 10^{-3 b}$ & & \\
\hline NOx & $\mathrm{kg}$ & $9.35 \times 10^{-2 \mathrm{e}}$ & $2.72 \times 10^{-1 b}$ & & \\
\hline $\mathrm{CH}_{4}$ & $\mathrm{Kg}$ & 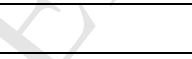 & $8.74^{\mathrm{b}}$ & & \\
\hline $\mathrm{H}_{2} \mathrm{~S}$ & $\mathrm{~kg}$ & $y$ & $5.79 \times 10^{-2 b}$ & & \\
\hline $\mathrm{SO}_{2}$ & $\mathrm{~kg}$ & $Y$ & $2.4 \times 10^{-3 b}$ & & \\
\hline $\mathrm{CO}$ & $\mathrm{kg}$ & & $6.71 \times 10^{-1 b}$ & & \\
\hline Particulates, $<2.5$ um & & & $1.51 \times 10^{-1 b}$ & & \\
\hline Acetaldehyde & $\mathrm{kg}$ & & $1.2 \times 10^{-4 b}$ & & \\
\hline Arsenic & $\mathrm{kg}$ & & $1.9 \times 10^{-6 b}$ & & \\
\hline Benzene & $\mathrm{kg}$ & & $1.73 \times 10^{-3 b}$ & & \\
\hline Benzene, ethyl- & $\mathrm{kg}$ & & $5.72 \times 10^{-5 b}$ & & \\
\hline Benzene, hexachloro- & $\mathrm{kg}$ & & $1.37 \times 10^{-11 b}$ & & \\
\hline Benzo(a)pyrene & $\mathrm{kg}$ & & $9.52 \times 10^{-7 b}$ & & \\
\hline Cadmium & $\mathrm{kg}$ & & $1.33 \times 10^{-6 b}$ & & \\
\hline Chlorine & $\mathrm{kg}$ & & $3.42 \times 10^{-4 b}$ & & \\
\hline Chromium & $\mathrm{kg}$ & & $7.54 \times 10^{-6 b}$ & & \\
\hline Chromium VI & $\mathrm{kg}$ & & $7.62 \times 10^{-8 b}$ & & \\
\hline Copper & $\mathrm{kg}$ & & $4.20 \times 10^{-5 b}$ & & \\
\hline $\begin{array}{c}\text { Dioxin, } 2,3,7,8 \\
\text { Tetrachlorodibenzo-p- }\end{array}$ & $\mathrm{kg}$ & & $5.90 \times 10^{-11 b}$ & & \\
\hline Formaldehyde & $\mathrm{kg}$ & & $2.48 \times 10^{-4 b}$ & & \\
\hline $\begin{array}{c}\text { Hydrocarbons, } \\
\text { aliphatic, alkanes, C10, }\end{array}$ & $\mathrm{kg}$ & & $1.73 \times 10^{-3 b}$ & & \\
\hline
\end{tabular}


ACCEPTED MANUSCRIPT

\begin{tabular}{|c|c|c|c|c|c|}
\hline branched & & & & & \\
\hline $\begin{array}{c}\text { Hydrocarbons, } \\
\text { aliphatic, unsaturated }\end{array}$ & $\mathrm{kg}$ & & $6 \times 10^{-3 b}$ & & \\
\hline Lead & $\mathrm{kg}$ & & $4.76 \times 10^{-5 b}$ & & \\
\hline $\mathrm{m}$-Xylene & $\mathrm{kg}$ & & $2.28 \times 10^{-4 b}$ & & \\
\hline Manganese & $\mathrm{kg}$ & & $3.24 \times 10^{-4 b}$ & & \\
\hline Mercury & $\mathrm{kg}$ & & $5.72 \times 10^{-7 b}$ & & \\
\hline Nickel & $\mathrm{kg}$ & & $1.14 \times 10^{-5 b}$ & & \\
\hline $\begin{array}{l}\text { NMVOC, non-methane } \\
\text { volatile organic } \\
\text { compounds }\end{array}$ & $\mathrm{kg}$ & & $1.71 \times 10^{-3 b}$ & & \\
\hline $\begin{array}{l}\text { PAH, polycyclic } \\
\text { aromatic hydrocarbons }\end{array}$ & $\mathrm{kg}$ & & $2.12 \times 10^{-5 b}$ & & \\
\hline Phenol, pentachloro- & $\mathrm{kg}$ & & $1.54 \times 10^{-8 b}$ & 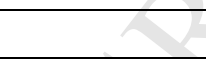 & $\square$ \\
\hline Phosphorus & $\mathrm{kg}$ & & $5.72 \times 10^{-4 b}$ & & \\
\hline Toluene & $\mathrm{kg}$ & & $5.72 \times 10^{-4 b}$ & ) & \\
\hline Zinc & $\mathrm{kg}$ & & $5.72 \times 10^{-4 b}$ & $\mathrm{C}$ & \\
\hline Emissions to water & & & 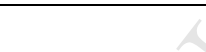 & & \\
\hline $\mathrm{NO}^{3-}$ & $\mathrm{kg}$ & $4.78^{c}$ & & $7.16 \times 10^{-5 b}$ & \\
\hline $\mathrm{PO}_{4}^{3-}$ & $\mathrm{kg}$ & $3.94 \times 10^{-2 f}$ & 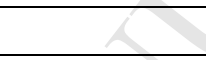 & 2 & \\
\hline$P$ & $\mathrm{~kg}$ & & 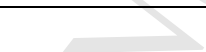 & & $1.88 \times 10^{-3 b}$ \\
\hline Emissions to soil & & & $\sqrt{x}$ & & \\
\hline Lead & $\mathrm{mg}$ & $51.9^{\mathrm{a}, \mathrm{g}}$ & 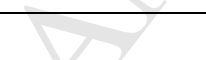 & & \\
\hline Cadmium & $\mathrm{mg}$ & $140^{\mathrm{a}, \mathrm{g}}$ & & & \\
\hline Chromium & $\mathrm{mg}$ & $1,480^{\mathrm{a}, \mathrm{g}}$ & $y$ & & \\
\hline Nickel & $\mathrm{mg}$ & $265^{\mathrm{a}, \mathrm{g}}$ & & & \\
\hline Copper & $\mathrm{mg}$ & $292^{a, g}$ & & & \\
\hline Zinc & $\mathrm{mg}$ & $2,460^{\mathrm{a}, \mathrm{g}}$ & & & \\
\hline Mercury & $\mathrm{mg}$ & $0.682^{a, g}$ & & & \\
\hline Arsenic & $\mathrm{mg}$ & $73.8^{a, g}$ & & & \\
\hline Thallium & $\mathrm{mg}$ & $3.93^{a, g}$ & & & \\
\hline Glyphosate & $\mathrm{kg}$ & $0.338^{a, g}$ & & & \\
\hline Metsulfuron-methyl & $\mathrm{kg}$ & $0.148^{a, g}$ & & & \\
\hline Paraquat & $\mathrm{kg}$ & $0.104^{a, g}$ & & & \\
\hline Cypermethrin & $\mathrm{kg}$ & $2.15 \times 10^{-2 \mathrm{a}, \mathrm{g}}$ & & & \\
\hline $\begin{array}{l}\text { Glufosinate } \\
\text { ammonium }\end{array}$ & $\mathrm{kg}$ & $3.20 \times 10^{-2} \mathrm{a}, \mathrm{g}$ & & & \\
\hline Methamidophos & $\mathrm{kg}$ & $3.20 \times 10^{-2} \mathrm{a}, \mathrm{g}$ & & & \\
\hline Carbofuran & $\mathrm{kg}$ & $3.50 \times 10^{-2 a, g}$ & & & \\
\hline Dimethylamine & $\mathrm{kg}$ & $3.10 \times 10^{-2 a, g}$ & & & \\
\hline Waste to treatment & & & & & \\
\hline Waste water & $\mathrm{kg}$ & & & & $16.5^{b}$ \\
\hline $\begin{array}{l}\text { Bleaching earth to } \\
\text { landfill }\end{array}$ & $\mathrm{kg}$ & & & & $1.51 \times 10^{-1 b}$ \\
\hline
\end{tabular}

${ }^{a}$ (Choo et al., 2011)

${ }^{\mathrm{b}}$ (Schmidt, 2007)

${ }^{c}$ (De Klein et al., 2006)

d (Drösler et al., 2013)

${ }^{\mathrm{e}}$ (Hutchings et al., 2013)

${ }^{f}$ (Nemecek and Schnetzer, 2012) 
${ }^{g}$ (Brockmann et al., 2014)

${ }^{\mathrm{h}}$ (faostat.fao.org/)

Table $\mathrm{n}^{\circ} 2: \mathrm{LCl}$ of the production of $30 \mathrm{~g}$ of cosmetic cream (primary data from the industrial partner)

\begin{tabular}{|l|l|l|}
\hline & Unit & Quantity \\
\hline Inputs & & \\
\hline APG & $\mathrm{g}$ & 1.5 \\
\hline Vegetable oil & $\mathrm{g}$ & 6.0 \\
\hline Nitrogen & $\mathrm{g}$ & 12.2 \\
\hline Tap water & $\mathrm{g}$ & 24.7 \\
\hline Energy & & \\
\hline Electricity & $\mathrm{kWh}$ & $2.1 \times 10^{-2}$ \\
\hline Steam & $\mathrm{g}$ & $2.5 \times 10^{-3}$ \\
\hline Transport lorry & $\mathrm{kgkm}$ & 6.3 \\
\hline Output & & \\
\hline Wastewater & $\mathrm{ml}$ & $3.0 \times 10^{-1}$ \\
\hline Mud to incineration & $\mathrm{g}$ & 2.1 \\
\hline
\end{tabular}




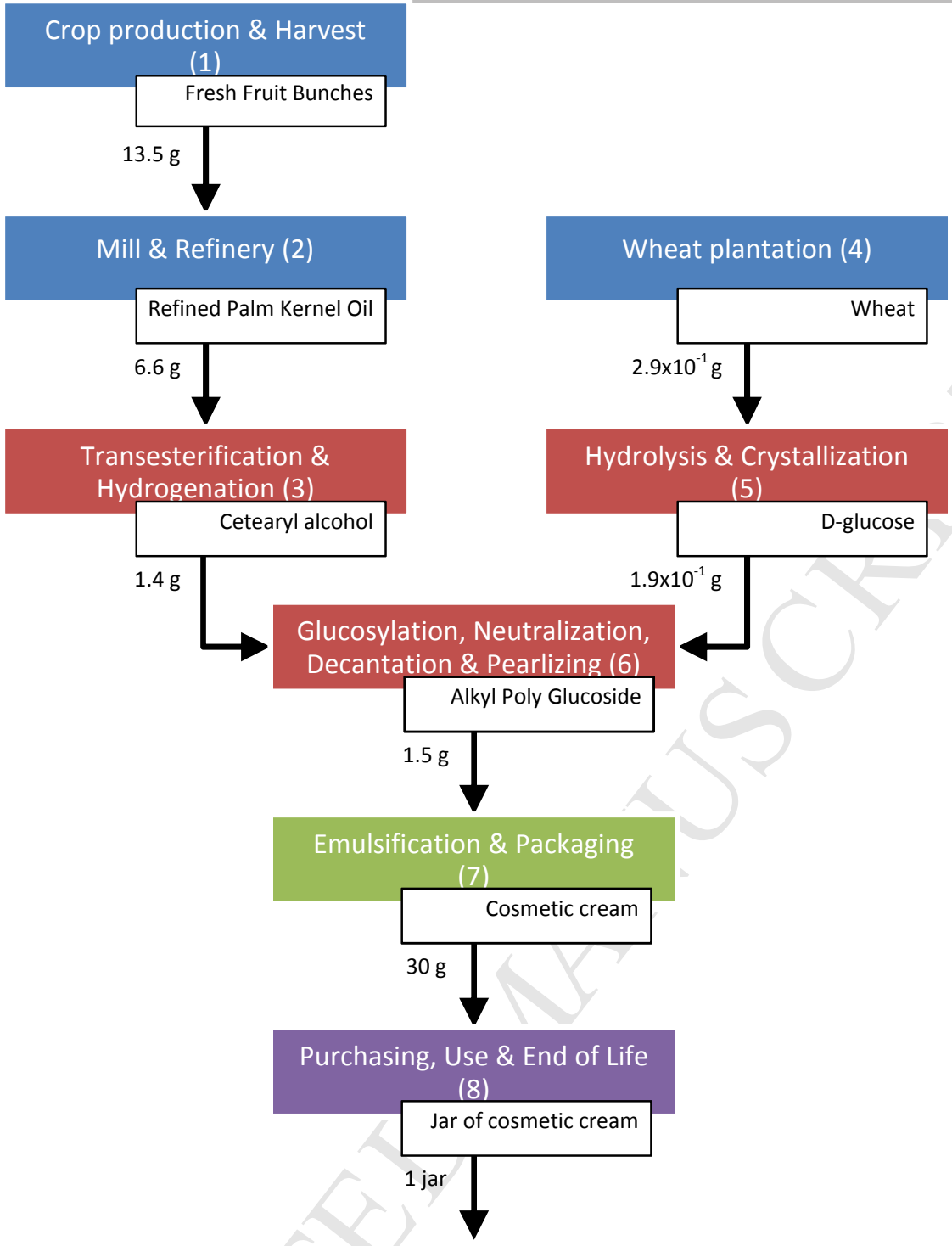

Fig 1: Overview of the global system for 1 jar of cosmetic cream. 


\begin{tabular}{|c|c|c|c|c|c|}
\hline & Cons. Waste & Transport & Packaging & Cosmetic cream & RPKO \\
\hline Acidification & $-1 \%$ & $49 \%$ & $23 \%$ & $23 \%$ & $\%$ \\
\hline Climate change & $0 \%$ & $53 \%$ & $19 \%$ & $24 \%$ & $3 \%$ \\
\hline Freshwater ecotoxicity & $11 \%$ & $73 \%$ & $6 \%$ & $8 \%$ & $2 \%$ \\
\hline Freshwater eutrophication & $-1 \%$ & $49 \%$ & $13 \%$ & $35 \%$ & $3 \%$ \\
\hline $\begin{array}{c}\text { Human toxicity, cancer } \\
\text { effects }\end{array}$ & $-1 \%$ & $68 \%$ & $17 \%$ & $13 \%$ & $2 \%$ \\
\hline $\begin{array}{l}\text { Human toxicity, non-cancer } \\
\text { effects }\end{array}$ & $4 \%$ & $61 \%$ & $18 \%$ & $16 \%$ & $2 \%$ \\
\hline Ionizing radiation $\mathrm{E}$ & $-32 \%$ & $33 \%$ & $59 \%$ & $7 \%$ & $1 \%$ \\
\hline Ionizing radiation $\mathrm{HH}$ & $-9 \%$ & $12 \%$ & $82 \%$ & $6 \%$ & $0 \%$ \\
\hline Land use & $0 \%$ & $36 \%$ & $5 \%$ & $54 \%$ & \\
\hline Marine eutrophication & $0 \%$ & $23 \%$ & $23 \%$ & $42 \%$ & \\
\hline Mineral \& fossil depletion & $0 \%$ & $82 \%$ & $4 \%$ & $13 \%$ & $2 \%$ \\
\hline Ozone depletion & $0 \%$ & $60 \%$ & $28 \%$ & $9 \%$ & $3 \%$ \\
\hline Particulate matter & $-1 \%$ & $55 \%$ & $19 \%$ & $22 \%$ & \\
\hline Photochemical ozone form. & $-1 \%$ & $55 \%$ & $24 \%$ & $18 \%$ & $3 \%$ \\
\hline Terrestrial eutrophication & $-1 \%$ & $49 \%$ & $19 \%$ & $24 \%$ & \\
\hline
\end{tabular}

Fig 2: LCA results of the continuous palm plantation on mineral soil (baseline scenario) 
FFB

Acidification

Climate Change

Freshwater Ecotoxicity

Freshwater Eutrophication

Human Toxicity Cancer

Human Toxicity Non cancer

Ion. Radiation E

Ion. Radiation $\mathrm{HH}$

Land use

Marine Eutrophication

Mineral \& fossil depletion

Ozone Depletion

Particulate Matter

Photochemical Ozone Form.

Terrestrial Eutrophication

\section{CPO}
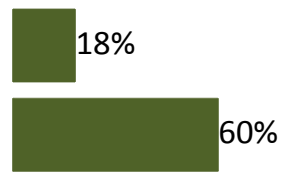

$85 \%$
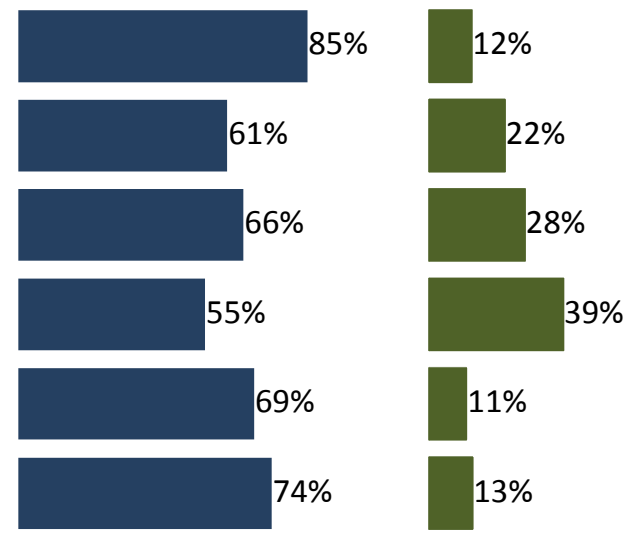

$11 \%$
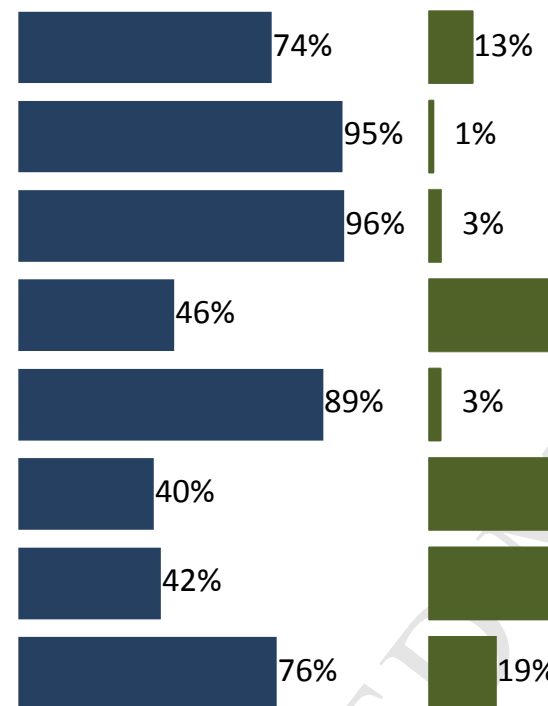

\section{Refinery}

$1 \%$

$2 \%$

$1 \%$

$15 \%$

$2 \%$

$2 \%$

$5 \%$

$4 \%$

$2 \%$

0\%

$1 \%$

$2 \%$

$1 \%$

$1 \%$

$0 \%$

\section{Transports}

$4 \%$

$4 \%$

$2 \%$

$2 \%$

$4 \%$

$4 \%$

$15 \%$

$10 \%$

$2 \%$

$1 \%$

$5 \%$

$5 \%$

$3 \%$

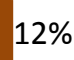

$4 \%$

Fig 3: LCA results of RPKO in baseline scenario 


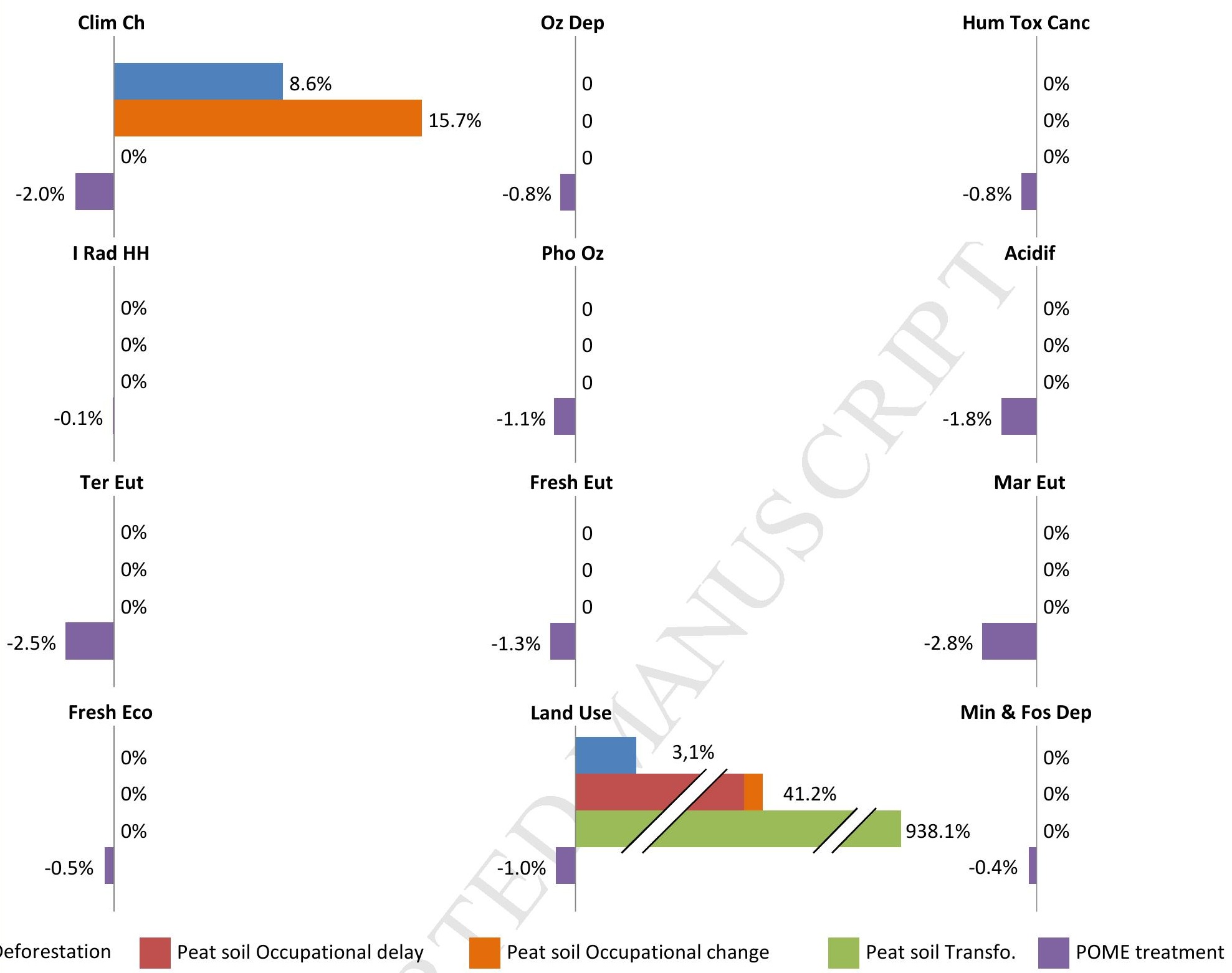

Fig 4: Influence of deforestation, peat soil transformation, peat soil occupation, POME treatment 
Highlights

- Transport and packaging contribute the most to all impacts over the cream life cycle

- $\quad$ Refined Palm Kernel Oil represents on average $20 \%$ of this total impact

- Deforestation increases Climate Change by $12 \%$ and Land Use impact by $6 \%$

- Peat soil occupation increases Climate Change by $22 \%$ and Land Use impact by $84 \%$

- Improving palm oil mill effluent treatment reduces impacts by $1.49 \%$ on average 